\title{
Consumer Response to Cigarette Excise Tax Changes
}

\section{Citation}

Chiou, Lesley and Erich J. Muehlegger. 2010. Consumer Response to Cigarette Excise Tax Changes. HKS Faculty Research Working Paper Series, RWP10-020, John F. Kennedy School of Government, Harvard University.

\section{Published Version}

http://web.hks.harvard.edu/publications/workingpapers/citation.aspx?Publd=7335

\section{Permanent link}

http://nrs.harvard.edu/urn-3:HUL.InstRepos:4448875

\section{Terms of Use}

This article was downloaded from Harvard University's DASH repository, and is made available under the terms and conditions applicable to Other Posted Material, as set forth at http:// nrs.harvard.edu/urn-3:HUL.InstRepos:dash.current.terms-of-use\#LAA

\section{Share Your Story}

The Harvard community has made this article openly available.

Please share how this access benefits you. Submit a story.

Accessibility 


\title{
Consumer Response to Cigarette Excise Tax Changes Faculty Research Working Paper Series
}

\author{
Lesley Chiou
}

Occidental College

\section{Eric Muehlegger}

Harvard Kennedy School

\section{J une 2010 RWP10-020}

The views expressed in the HKS Faculty Research Working Paper Series are those of the author(s) and do not necessarily reflect those of the John F. Kennedy School of Government or of Harvard University. Faculty Research Working Papers have not undergone formal review and approval. Such papers are included in this series to elicit feedback and to encourage debate on important public policy challenges. Copyright belongs to the author(s). Papers may be downloaded for personal use only. 


\title{
Consumer Response to Cigarette Excise Tax Changes
}

\author{
Lesley Chiou Erich Muehlegger *
}

May 19, 2010

\begin{abstract}
We use a rich dataset of weekly cigarette sales to examine how consumers adapt their behavior before and after excise tax increases - whether by reducing demand, stockpiling, traveling to low-tax jurisdictions, or substituting towards lower-cost brands. Consumer response varies substantially for different types of cigarettes. Stockpiling primarily occurs for discount cigarettes and is most pronounced at stores far from lower-tax jurisdictions. Border-crossing is greatest at stores close to low-tax jurisdictions and occurs primarily for cigarettes sold by the carton. Finally, we find modest short-run substitution towards lower-cost brands following a tax-increase, consistent with consumers smoothing the transition to higher cigarette taxes. These differences in consumer behavior lead to meaningful differences in tax incidence - pass-through is higher for discount cigarettes which have more inelastic demand. Pass-through is lower near low-tax borders, especially for cigarettes sold by the carton for which cross-border evasion is greatest.
\end{abstract}

Key Words: Cigarettes; Consumer Behavior; Excise Taxes; Stockpiling; Tax Avoidance; Tax Incidence.

JEL: D1, D4, H2, H7

*(Chiou) Occidental College. email: lchiou@oxy.edu. (Muehlegger-corresponding author) Harvard Kennedy School and National Bureau of Economic Research. 79 John F. Kennedy St. Cambridge, MA, 02138. ph: 617-335-6083. email: Erich_Muehlegger@hks.harvard.edu. We would like to thank Michael Lovenheim for valuable comments and feedback. We thank Kate Mikels and Andrew Lai for excellent research assistance. We would also like to thank Brian Carlson of the Chicago Department of Revenue and Stephen O'Sullivan of the city of Evanston for providing information on local cigarette taxes. Funding for the project came partially from the Institute of Politics at Harvard Kennedy School. 


\section{Introduction}

Many taxes, from cigarette taxes to proposed carbon taxes, are motivated by non-fiscal considerations. While a great number of studies estimate short and long-run tax elasticities, fewer are able to examine how consumers adapt their behavior to tax changes. Although the tax elasticity of demand is useful for fiscal considerations, it provides an incomplete picture of whether the observed consumer response represents an actual reduction in consumption of the taxed good or whether it represents some form of consumer tax avoidance or behavior change. In this paper, we study how consumers respond to cigarette excise tax increases by examining weekly sales of cigarettes at approximately 85 supermarkets in the Chicago metropolitan area between 1989 and 1996. Our micro-data allows us to closely investigate the different margins by which consumers may respond to a tax change. In particular, we can distinguish and empirically test four different margins by which consumers respond to rising taxes: (1) reducing consumption, (2) stockpiling the good prior to the tax change, (3) substituting from high-price premium to low-price discount versions of the good, and (4) shifting purchases from high-tax jurisdictions to lower-tax jurisdictions. Our study is unique in that we are able to examine both shortand long-run adaptation to tax changes over time with micro-data. As consumers can mitigate the effects of a rising tax on their consumption by stockpiling, substitution across brands, and shifting the location of their purchases, our work has important implications for non-fiscal tax efficacy, especially for "sin" taxes designed to discourage consumption.

Our empirical strategy overcomes three challenges commonly faced in distinguishing how smokers adapt behavior in response to tax changes. First, data on consumer purchases are rarely reported frequently enough to identify stockpiling from idiosyncratic changes in tastes. Second, few datasets distinguish between different quality-tiers of a taxed good. Aggregation across different quality-tiers obscures the identification of consumer substitution from high-price to low-price brands which may occur following a tax increase. Finally, few studies track sales at a highly disaggregated geographic level; most of the previous cigarette literature uses indirect estimates of border-crossing from high-tax to low-tax counties or states.

We are able to overcome these challenges by using a dataset which reports weekly sales at the Universal Product Code (UPC) level at individual supermarkets in the Chicago area. We observe sales with high frequency, allowing us to examine the intertemporal pattern of sales around state and local cigarette tax changes. Furthermore, we observe prices and quantities of each particular UPC sold (e.g., Marlboro 120s, sold in individual soft packs) at each store. The UPClevel data distinguishes sales of single-packs from cartons as well as sales of different cigarette 
quality-tiers, which allows us to investigate and estimate substitution between these categories following a tax change. Finally, the supermarkets that we observe are located throughout the Chicago metropolitan area and vary demographically as well as in proximity to the Indiana and Wisconsin borders. Thus, we are able to observe how consumers near or far from lower-tax borders respond as taxes rise. We also examine whether consumer response is correlated with customer demographics - for instance, wealthy smokers may more easily absorb a tax increase without switching to cheaper, discount brands.

To motivate our empirical analysis, we first use an event study to examine a change in the Illinois tax in July 1993 that increased the state cigarette tax by approximately $46 \%$ from 30 to 44 cents per pack. We use this discrete change in cigarette taxes to closely examine how consumers shift their behavior during the short-run prior to and in the aftermath of this large tax change - whether by stockpiling cigarettes in anticipation of the tax increase or by changing the type, quantity, and/or location of cigarettes purchased afterwards. We find evidence that consumers do anticipate tax increases by stockpiling in the months prior to the tax increase and that this behavior differs markedly by quality-tier and location. While we do not observe stockpiling of premium cigarettes, we observe a dramatic increase $(>200 \%)$ in the sales of discount cigarettes in the month prior to the tax change. Moreover, stockpiling is more pronounced at stores located far from the borders of Indiana and Wisconsin, where the costs of traveling to a lower-tax jurisdiction are greater.

We extend the analysis by constructing a longer panel over the period 1989 to 1996, which includes two federal tax increases in January 1991 and January 1993, the July 1993 state tax increase in Illinois, local cigarette tax increases in Cook County, the municipalities of Chicago and Evanston, and tax increases the neighboring states of Wisconsin and Indiana. The longer panel allows us to better test for stockpiling as well as other long-run methods of adaptation, such as switching from more expensive to less expensive cigarette brands or crossing to neighboring jurisdictions with lower tax rates. Our estimates imply that a one-cent increase in cigarette prices is associated with approximately a four percent increase in the sales of discount cigarettes during the month preceding the tax increase. Similarly to our event study results, we find that stockpiling of discounted cigarettes is greater at stores far from the Indiana border. We do not find strong evidence that stockpiling is correlated with store demographics - we only find that stockpiling is negatively correlated with a store's proportion of minority customers.

We find suggestive evidence that consumers shift between cigarette quality-tiers as taxes rise. The model we present in section 2 suggests that, absent addiction, consumers will tend to 
shift towards more expensive brands as per-unit excise taxes rise and the relative prices between different quality tiers declines. Over the long term, our panel analysis finds evidence consistent with this prediction. For most locations, tax increases are associated with a shift towards higher quality cigarettes in the long-run. This effect declines as the percentage of customers who are minority or over 60 years of age increases; these customers may permanently substitute away from premium brands in favor of cheaper discount cigarettes. In the short-run, though, discount cigarette sales rise after a tax increase, even after controlling for cigarette prices. This is consistent with a basic model of addiction - consumers may shift in the short-run to lower quality cigarettes in order to smooth the transition to higher cigarette prices.

Finally, we find that border-proximity and strength of the incentive to travel to lower tax jurisdictions is associated with a reduction in cigarettes sales. The reduction in sales occurs only for cigarettes sold by the carton - exactly the class of products for which we would expect border-crossing to be the greatest. We estimate that sales of cigarettes sold by the carton are approximately forty-four percent lower at a store five miles from the Indiana border facing the average tax differential during the period ( 24 cents per pack) than a store of average distance from the Indiana border ( $\sim 27$ miles $)$. We do not find a similar effect for cigarettes sold by the pack.

These differences in consumer response translate into meaningful differences in tax incidence. We find that pass-through is greater for discount cigarettes, for which we estimate the demand to be most price inelastic, than for premium brands. We also find that tax pass-through is lower for cigarettes sold by the carton. In a similar fashion to Doyle and Samphantharak (2008), we also find that pass-through declines near low-tax borders, where the elasticity of demand is likely to be greater. This effect is especially pronounced for cigarettes sold by the carton - the class of cigarettes for which we estimate border-crossing to be the greatest.

In addition to contributing the literature on smoker response to cigarette taxes (e.g., Coats (1995), Yurekli and Zhang (2000), Adda and Cornaglia (2006)), our paper informs the growing literature examining short-run consumer response to taxes. In the durable goods context, Sallee (2008) examines the intertemporal response of consumers' automobile purchases, exploiting the January 2005 increase in value of federal hybrid vehicle incentives. Sallee finds a significant delay in purchases of hybrid vehicle at the end of 2004, consistent with consumer anticipation of the increase in the value of the hybrid vehicle incentive. In contrast, we examine non-durable good purchases - for which stockpiling is possible and substitution between high- and low-quality versions of a taxed good likely differ. Our paper also relates to the literature on border-crossing 
behavior due to differences in taxes across jurisdictions (Stehr (2007); Lovenheim (2008); Chiou and Muehlegger (2009)).

In section 2 , we present a stylized model of cigarette consumption which we use to motivate our empirical predictions. In section 3, we present our data. Section 4 discusses the results of our two empirical approaches. Section 5 concludes.

\section{Model}

To motivate our empirical analysis and our discussion of how smokers may adapt their behavior to tax changes, we consider a stylized two-period game in which smokers choose between two classes of cigarettes: a "premium" brand sold at price $p_{b}$ and a "discount" brand sold at price $p_{d}$. Smokers consume cigarettes in both periods and can also stockpile cigarettes in the first period in anticipation of a per-pack tax increase $t$. Denoting consumption of premium and discount cigarettes in periods 1 and 2 as $q_{1 b}, q_{2 b}, q_{1 d}$, and $q_{2 d}$, consumption of the outside good as $z_{1}$ and $z_{2}$, and stockpiling of premium and discount cigarettes in period 1 as $x_{b}$ and $x_{d}$, consumers maximize

$$
\begin{aligned}
U\left(q_{1 b}, q_{2 b}, q_{1 d}, q_{2 d}, z_{1}, z_{2}\right)= & \alpha f\left(q_{1 b}+\gamma q_{1 d}\right)+g\left(z_{1}\right)+\delta\left[\alpha f\left(q_{2 b}+x_{b}+\gamma q_{2 d}+\gamma x_{d}\right)+g\left(z_{2}\right)\right] \\
& \left.-\delta \beta h\left(q_{1 b}+q_{1 d}-\left(q_{2 b}+x_{b}+q_{2 d}+x_{d}\right)\right)\right]
\end{aligned}
$$

subject to non-negativity constraints and budget constraints

$$
\begin{aligned}
& p_{b}\left(q_{1 b}+x_{b}\right)+p_{d}\left(q_{1 d}+x_{d}\right)+z_{1}=B \\
& \left(p_{b}+t\right) q_{2 b}+\left(p_{d}+t\right) q_{2 d}+z_{2}=B .
\end{aligned}
$$

The function $f$ denotes utility derived from cigarette consumption, and the function $g$ denotes denotes utility derived from non-smoking consumption. In addition, we include a function $h$, which captures the addiction disutility associated with reducing consumption in the post-tax period. We assume that $f$ and $g$ are increasing and concave and that $h$ is increasing and convex. Consumers are heterogeneous with $\alpha$ representing consumer preference for smoking, $\gamma$ denoting heterogeneous consumer preference for discount cigarettes, and $\beta$ denoting the degree to which consumers incur disutility from reducing their cigarette consumption. We define $\delta<1$ as the rate at which a consumer discounts future consumption.

By construction, a consumer will have an exclusive preference for premium or discount 
cigarettes depending on their value of gamma. We use $\hat{\gamma}_{1}, \hat{\gamma}_{2}$ and $\hat{\gamma}_{x}$ to denote the unique threshold values at which a consumer is indifferent between purchasing discount and premium cigarettes in period 1, period 2, and as inventories between the low-tax and high-tax periods. A consumer with value of $\gamma$ above a threshold (i.e., a greater preference for discount cigarettes) will purchase discount cigarettes exclusively, while a consumer with a value of $\gamma$ below the threshold will exclusively purchase premium cigarettes.

$$
\begin{aligned}
& \hat{\gamma}_{1}=\frac{\beta h^{\prime}\left[p_{b}-p_{d}\right]}{\alpha f^{\prime}\left(p_{b}\right)}+\frac{p_{d}}{p_{b}} \\
& \hat{\gamma}_{2}=\frac{-\beta h^{\prime}\left[p_{b}-p_{d}\right]}{\alpha f^{\prime}\left(p_{b}+t\right)}+\frac{p_{d}+t}{p_{b}+t} \\
& \hat{\gamma}_{x}=\frac{-\beta h^{\prime}\left[p_{b}-p_{d}\right]}{\alpha f^{\prime}\left(p_{b}\right)}+\frac{p_{d}}{p_{b}}
\end{aligned}
$$

Absent addiction (where $\beta=0$ ), the threshold value of $\gamma$ depends exclusively on the relative prices of discount and premium cigarettes. Consequently, as per-pack taxes rise, the threshold shifts in favor of premium cigarettes. ${ }^{1}$ With addiction, a forward-looking consumer will shift, on the margin, towards premium cigarettes in the first period, recognizing that smoking fewer cigarettes reduces the disutility of lowering consumption when taxes rise. On the other hand, addiction shifts consumers towards stockpiling discount cigarettes. In addition, in the post-tax period, addiction shifts consumers on the margin towards discount cigarettes in the short-run, at least until the smoker is able to wean themselves to a lower level of consumption in the long-run.

Conditional on $\alpha$ and $\beta$, the thresholds define four classes of smokers: (1) individuals who only smoke or stockpile premium cigarettes, (2) individuals who stockpile discount cigarettes, but purchase premium cigarettes for immediate consumption, (3) individuals who stockpile discount cigarettes, and purchase discount cigarettes for consumption in one but not both of the pre-tax and post-tax period, and (4) individuals who only smoke or stockpile discount cigarettes. ${ }^{2}$ As the disutility associated with reducing cigarette consumption rises, the threshold value of $\hat{\gamma}_{x}$ falls, and we would expect that consumers would stockpile discount cigarettes. In addition, $\hat{\gamma}_{1}$ declines relative to $\hat{\gamma}_{2}$, implying some consumers may switch from premium to discount cigarettes in the post-tax period to smooth their reduction in cigarette consumption.

Although the tax does not affect the proportion of consumers who stockpile premium and discount cigarettes, the tax does affect the amount of cigarettes a consumer chooses to stock-

\footnotetext{
${ }^{1}$ This implicitly assumes that tax pass-through for the discount and premium cigarettes is equivalent - a hypothesis we are able to test empirically.

${ }^{2}$ Whether group (3) are individuals who smoke premium cigarettes pre-tax and discount cigarettes post-tax or vice versa depends on the functional form of $\mathrm{f}$ and $\mathrm{h}$. These consumers will switch from premium to discount cigarettes when $\hat{\gamma}_{1}>\hat{\gamma}_{2} \Longleftrightarrow \frac{\beta h^{\prime}\left(p_{b}-p_{d}\right)}{\alpha f^{\prime}\left(p_{b}\right)}+\frac{\beta h^{\prime}\left(p_{b}-p_{d}\right)}{\alpha f^{\prime}\left(p_{b}+t\right)}>\frac{p_{d}+t}{p_{b}+t}-\frac{p_{d}}{p_{b}}$.
} 
pile. ${ }^{3}$ Depending on how $\gamma$ compares to $\hat{\gamma}_{1}, \hat{\gamma}_{2}$ and $\hat{\gamma}_{x}$, consumers purchase premium or discount cigarettes exclusively in period 1 , period 2 , or as inventories, and three of the nonnegativity constraints will bind. The first-order conditions are standard and imply the usual three equalities. As an example, for a smoker who only chooses to smoke or stockpile premium cigarettes (with a value of $\left.\gamma<\frac{-\beta h^{\prime}\left[p_{b}-p_{d}\right]}{\alpha f^{\prime} p_{b}}+\frac{p_{d}}{p_{b}}\right)$, the three equalities

$$
\begin{aligned}
& \frac{\alpha f^{\prime}\left(q_{1 b}\right)-\delta \beta h^{\prime}\left(q_{1 b}-q_{2 b}-x_{b}\right)}{p_{b}}=g^{\prime}\left(z_{1}\right) \\
& \frac{\alpha f^{\prime}\left(q_{2 b}+x_{b}\right)+\beta h^{\prime}\left(q_{1 b}-q_{2 b}-x_{b}\right)}{p_{b}+t}=g^{\prime}\left(z_{2}\right) \\
& \frac{\delta \alpha f^{\prime}\left(q_{2 b}+x_{b}\right)+\delta \beta h^{\prime}\left(q_{1 b}-q_{2 b}-x_{b}\right)}{p_{b}}=g^{\prime}\left(z_{1}\right)
\end{aligned}
$$

equate the marginal utility per dollar of cigarette and non-cigarette consumption in the first period, the second period, and intertemporally through the inventory constraint. In all cases, the comparative statics are consistent with intuition. The imposition of taxes increases inventories while reducing both classes of consumption in the first period.

\section{Empirical Model and Data}

Our empirical analysis relies on scanner data of cigarette sales from Dominick's Finer Foods (hereafter, DFF) provided by the Kitts Center for Marketing at Chicago GSB. ${ }^{4}$ Dominick's Finer Foods is the second largest supermarket chain in the Chicago metropolitan area with a market share of approximately 25 percent (Chevalier et al., 2003). The DFF scanner dataset provides weekly, UPC-level data for twenty classes of products, from orange juice to pain medication to laundry detergent at 120 DFF grocery stores in Lake, Cook, Dupage and Will Counties, from 1989 to 1996. For our purposes, we focus specifically on the scanner data related to cigarettes for which per pack taxes were raised at various points by the state of Illinois, Cook County, and neighboring jurisdictions. The DFF data track cigarette sales at approximately 83 of the stores.

For each cigarette UPC with positive sales in a particular store-week, the scanner data reports the total number of units sold (reported in packs for UPCs corresponding to products sold by the pack and reported in cartons for products sold by the carton). In addition, the scanner data reports the retail price for each UPC with positive sales. ${ }^{5}$ Because the DFF scanner data only

\footnotetext{
${ }^{3}$ Although we do not formally present it, for sake of brevity, the model extends in a relatively straightforward fashion to one in which consumers have an additional option of traveling to a lower cost jurisdiction. In this case, the value to stockpiling is lower, especially for consumers who can travel to the low-tax jurisdiction at low cost.

${ }^{4}$ The DFF data is publicly available at http://research.chicagogsb.edu/marketing/databases/dominicks/index.aspx.

${ }^{5}$ As excise taxes are remitted by wholesalers, the store will not likely observe the pre-tax price for cigarettes.
} 
reports quantities and prices for products offered by Philip Morris for a subset of the time period, we restrict our analysis to sales of cigarettes produced by the three other major manufacturers: Lorriard, Liggett, and R J Reynolds. For our three manufacturers, we observe positive sales for 348 distinct UPC codes. Approximately 34 percent of UPCs have positive sales in any particular week. In total, we observe sales of 13.2 million packs of cigarettes in our sample. ${ }^{6}$

We categorize UPCs into "premium" and "discount" products based on the observed retail prices. For each UPC with recorded sales, we normalize the retail price by the unweighted average price of all the cigarettes sold in the same store and week. The normalized retail price quantifies the markup (or discount) at which a particular UPC is priced relative to the average per pack cigarette price in a particular store and week. We then average the weekly, storespecific ratios for each UPC across stores and over time to calculate how much, on average, a product's posted price is discounted relative to other brands. That is, if $J$ denotes the set of store-week observations, and UPC $i$ has positive sales in the subset $J_{i} \subseteq J$, consisting of $n_{i}$ store-weeks, we construct our proxy as

$$
\operatorname{RelPrice}_{i}=\frac{\sum_{j \in J_{i}} p_{i j} / p_{j}}{n_{i}}
$$

where $p_{i j}$ denotes UPC $i$ 's per-pack price in store-week $j$, and $p_{j}$ denotes the sales-weighted average per-pack price for cigarettes sold by the pack (or by the carton if UPC $i$ represents carton-level sales).

We find that top of the cigarettes price distribution tends to be closely clustered. Prices for the most expensive half of UPCs are within two to three percent of each other. Other UPCs are sold at varying levels of discount. We classify UPCs that sell at a ten-percent or greater discount on average as "discount" cigarettes. The lowest decile of cigarettes (partially comprised by the brands Doral, Winston, and Magna) are priced at a 13 and 16 percent discount relative to the majority of the per pack prices. As a point of comparison, the least expensive UPCs in our sample sell at 25 percent discounts on average. Products we classify as "discount" based on the average relative prices correspond well to binary industry classifications of "premium" and "discount" cigarettes.

We collected data on excises taxes levied by the federal government, Illinois, and neighboring states from the Tax Burden on Tobacco. We obtained information on county and municipal

Average prices of cigarettes in our sample are similar to figures reported for tax-inclusive prices in the Tax Burden of Tobacco (2007).

${ }^{6}$ Cigarettes sales by R. J. Reynolds, Lorillard, and Liggett total 8.4 million packs, 4.2 million packs, and 0.6 million packs respectively. 
excises taxes from city ordinances online and from speaking with local government officials. ${ }^{7}$ Federal taxes increased at two points in our sample. On January 1, 1991, the federal excise tax increased from 16 to 20 cents per pack, and on January 1, 1993, the federal excise tax increased again to 24 cents per pack. State excise taxes increased during the period as well. Illinois raised its state cigarette tax from 30 to 44 cents per pack in July 1993 (week 200 in Figure 1). The excise tax in Indiana remained constant at 15.5 cents per pack while the tax in Wisconsin increased from 30 to 38 cents in May 1992 and to 44 cents in September 1995.

In addition to state and federal taxes, some of the stores are subject to county and local excise taxes. Cook County, Illinois levies a separate excise tax on cigarettes. Cook County increased the excise tax from 10 cents per pack at the beginning of the period to 18 cents in March 1996. Additionally, two cities levy municipal excise taxes on cigarettes. The city of Chicago had a 16 cent per pack excise tax, and the city of Evanston maintained a 10 cent per pack excise tax. Twenty five of the stores in our sample were located outside of Cook County. Thirty-eight were located within Cook County, but outside of Chicago or Evanston. Seventeen were located within the Chicago city limits, and three were located within the Evanston city limits.

Figure 1 displays the per-pack excise tax in four jurisdictions where DFF stores are located: within-Chicago, within-Evanston, within Cook-county but outside of Chicago/Evanston, and outside of Cook County. In addition, Figure 1 displays the per-pack excise tax in Indiana and Wisconsin. In Figure 2, we graph the excise taxes in the four jurisdictions relative to excise taxes in Wisconsin.

Table 1 reports the summary statistics for the data. For the mean store-week, four hundred packs are sold. Approximately half of the cigarettes are sold the carton. The average price for cigarettes is $\$ 2.32$ per pack for all cigarettes, $\$ 2.09$ per pack for all cigarettes sold by the carton and $\$ 2.03$ per pack for discount cigarettes. The mean cigarette excise tax (including federal, state and local taxes) for stores in our sample is 73.8 cents per pack, or approximately 24 percent of the mean tax-inclusive price. Across all stores and over the entire time period, customers could save on average 35.3 cents per pack by traveling to Indiana and 12.2 cents per pack by traveling to Wisconsin.

In addition to sales, we observe the characteristics of each store. Using the reported latitude and longitude for each store in the DFF dataset, we calculate the straight-line distance to Indiana and Wisconsin. On average, the stores are 27.5 miles from the Indiana border and 42.9

\footnotetext{
${ }^{7}$ City ordinances can be found at the city websites or at http://www.amlegal.com and http://www.municode.com.
} 
miles from the Wisconsin border. The nearest stores are 2.0 miles from the Indiana border and 11.8 miles from the Wisconsin border. The DFF dataset also provides information about the demographics of store customers. Across stores, median household income varies from a low of approximately $\$ 19,300$ for the store with the least-wealthy customers to a high of $\$ 73,100$ for the store with the most-wealthy customers. Mean age, the fraction of minority customers, the fraction with a 4-year college degree, and the fraction living below the poverty line vary substantially as well.

\section{Results}

We apply two empirical approaches to the data described in the previous section in order to distinguish the different margins by which consumers adapt to tax changes. First, we examine the discontinuous increase in the Illinois tax in July 1993. This large tax change allows us to examine short-run consumer behavior; in particular, we test for evidence of stockpiling in anticipation of the tax increase and examine whether stockpiling varies for different classes of cigarettes and with proximity to low-tax borders. We then extend this analysis to the entire sample by constructing a panel from 1989 to 1996 of taxes, cigarette sales, and cigarette prices. Using the panel, we estimate stockpiling as well as longer run methods of adaptation, such as switching between more and less expensive cigarettes and border crossing.

\subsection{Event Study}

Our first approach exploits the discontinuous change in the Illinois state taxes in July 1993. The $46 \%$ increase in per-pack taxes represents the largest tax increase in our sample. Figure 3 graphs the sales of premium and discount cigarettes in the weeks immediately preceding and following the tax change in June 1993 (week 200). The sales are normalized by the corresponding quantities in week 171. As seen in the figure, suggestive evidence of stockpiling is present for discount cigarettes. A large rise occurs in the sales of discount cigarettes in the weeks immediately preceding the tax change. No such increase in premium brand sales can be seen.

Figure 4 graphs premium and discount sales for stores within 15 miles, between 15 and 30 miles, and more than 30 miles from the Indiana border. Cigarette sales are substantially lower at stores close to the Indiana border where residents are located near a lower-tax jurisdiction.

The figure suggests that no surge in sales prior to the tax increase occurred in stores within 20 miles of the border. Further away from the Indiana border, stockpiling of discount cigarettes emerges. Moreover, the percentage increase in discount sales is greatest for stores more than 20 
miles from the Indiana border where residents may have difficulty purchasing cigarettes from lower-tax jurisdictions. No such pattern exists for premium cigarettes at these store locations.

To more formally investigate stockpiling, substitution from "premium" to "discount" cigarettes, and cross-border substitution, we employ a simple event study regression to control for storespecific factors that may account for these differences over time. We normalize sales so that quantities for all categories of cigarettes (e.g., whether sold in packs or cartons) are measured in packs. We estimate the following regression for the logarithm of the total number of packs sold at store $j$ in week $t$ in a ten-month window surrounding the Illinois tax increase:

$$
\log \left(q_{j t}\right)=\beta_{0}+\sum_{s=3}^{8} \beta_{s} D_{s, t}+\beta_{9} D p l u s_{t}+\theta_{j}+\epsilon_{i t}
$$

where $D$ is a monthly dummy, and store fixed effects $\theta$ control for unobservable time-invariant differences in smoking preferences by store. For our ten-month window, we use the first two months as a baseline period when behavior was unlikely to be affected by the future tax change, and we include monthly dummies for each month thereafter (months 3 through 8 ). The variable Dplus is a dummy for all months after month 8 . The tax change occurs at the end of month 5 / start of month 6, so we interpret the coefficients on the monthly dummies as changes in consumption due to the tax change. For instance, if consumers do stockpile cigarettes in anticipation of the tax increase, we would expect $\beta_{3}, \beta_{4}$ and $\beta_{5}$ to be positive. Moreover, if stockpiling increases close to the date of the tax change, we would expect $\beta_{3}, \beta_{4}$ and $\beta_{5}$ to be monotonically increasing.

Table 2 reports our OLS regression results over our ten-month window surrounding the July 1993 Illinois tax increase. We are interested in how sales evolve over this time frame relative to the baseline period. Columns (1)-(3) report sales for all cigarettes and by brand (premium or discount). Even controlling for store-specific factors, we find suggestive evidence of stockpiling, as the estimated coefficients indicate that immediately preceding the tax increase, sales of total cigarettes gradually increase by 6 percent three months prior to the tax increase, by 25 percent two months before, and by 40 percent in the immediate month prior to the tax increase. Sales also begin to decline after the tax increase with sales eventually 16 percent lower after the third month.

To more closely examine the pattern of stockpiling and investigate whether it varies by discount or premium cigarettes, we decompose cigarettes sales into the two categories of discount and premium cigarettes, and we re-run the regression in equation (10). We find that the large increase in sales prior to the tax change occurred primarily from the increase in discount sales; 
no such surge occurred for the sales of premium cigarettes in the weeks preceding the tax change. Consistent with the figure 3 , we find that even after controlling for store-specific factors, evidence of stockpiling exists in anticipation of the tax increase. Moreover, after the tax increase, sales for discount cigarettes gradually decrease. This could be due to lags in the reporting of the data or to some switching from brand cigarettes initially.

To examine whether stockpiling and switching behavior differs between stores that are located near a lower-tax jurisdiction, we split our data into two samples: stores that are within 20 miles of Indiana (the nearest jurisdiction with substantially lower taxes) and stores that are located further away. ${ }^{8}$ Table 3 reports the results of our regressions. As expected, greater stockpiling of discount cigarettes occurs in stores located far from the Indiana border; consumers located far from the border are more likely to accumulate cigarettes in anticipation of a tax increase. Columns (1) and (2) show that sales in stores located far from borders increase in the month prior to the tax change with no comparable increase in sales for stores located near the border. Furthermore, Columns (5) and (6) indicate that the increase in stockpiling at stores far from the Indiana border occurs primarily for the sales of discount cigarettes. This stockpiling of discount cigarettes is more pronounced at stores located far from the Indiana border. Once again, no evidence of stockpiling exists for premium cigarettes in any stores. After the tax increase, sales of discount cigarettes fall more rapidly at stores located near borders, as consumers switch to lower-cost alternatives nearby. Sales of discount cigarettes decrease more slowly at stores far from the border. This suggests a short-run adaptation towards purchasing discount cigarettes in the immediate aftermath of a tax increase, particularly when lower-tax alternatives are not readily present.

This event study suggests that the smokers of premium and discount cigarettes respond differently to an anticipated tax increase. This pattern persists even controlling for store fixed effects. In the next section, we use these facts to motivate our panel analysis of the effects of various tax increases over a longer period and to more closely investigate the different margins of consumer response to tax changes.

\subsection{Panel Regressions}

We extend our event study analysis by constructing a longer panel that includes two federal tax changes, the 1993 tax change in Illinois, and tax changes in Wisconsin and Cook County. We

\footnotetext{
${ }^{8}$ Although some smokers may travel to Wisconsin as well, the tax differential is substantially smaller. In fact, prior to the July 1993 tax increase, the per-pack excise tax in Wisconsin was eight cents per pack higher than that in Illinois. The per-pack excise tax in Indiana, on the other hand, was twelve cents lower prior to the tax change.
} 
exploit the tax changes as well as heterogeneity in store location and demographics to examine both consumers' short-run and longer-run responses to tax changes.

We estimate the following demand regression for store $j$, class $k$ in week $t$ :

$$
\begin{aligned}
\log \left(q_{j k t}\right)= & \alpha_{1} \log \left(p_{j k t}\right) \\
& +\beta_{1}\left(\tau_{j, t+4}-\tau_{j, t}\right)+\beta_{2}\left(\tau_{j, t+4}-\tau_{j, t}\right) * \text { Discount }_{k}+\beta_{3}\left(\tau_{j, t+4}-\tau_{j, t}\right) X_{j k t} \\
& +\beta_{4} \text { dtax }_{j t} / \text { dist }_{j}+\beta_{5}\left(\text { dtax }_{j t} / \text { dist }_{j}\right) * \text { Carton }_{k} \\
& +\theta_{j k}+\delta_{1 k} t+\delta_{2 k} t^{2}+\delta_{3 k} t^{3}+\delta_{4 k} t^{4}+\epsilon_{j k t} .
\end{aligned}
$$

where $q_{j k t}$ is total cigarette sales in class $k$ at store $j$ in week $t, p_{j k t}$ is the average tax-inclusive per-pack price, and $\tau$ is the total federal, state and local excise tax per pack. We aggregate sales of four classes of cigarettes (premium cartons, premium packs, discount cartons, and discount packs). We include store*class fixed effects to control for time-invariant preferences for different cigarettes at different stores and estimate a separate quartic time trend for each class. The vector $X$ contains demeaned store demographics, such as the fraction of the store's clientele with a 4-year college degree, over 60 years of age, and minority as well as median income. We include the logarithm of price as an independent variable to capture changes in consumption due to changes in prices, and we incorporate differences in excise taxes to the nearest low-tax border to capture the incentive of consumers to cross-borders.

We use a similar identification strategy to Hausman (1997) and Nevo (2001). Our identifying assumption is that prices are a function of supply and demand conditions unique to each supermarket, supply conditions common across all supermarkets, and the per-unit excise tax. As instruments for price, we use the log of mean cigarette price at all other supermarkets as well as the tax appropriate to the store's location. After including store fixed effects, class fixed effects and class-specific quartic time trends, the identifying assumption is that demand at a given supermarket is uncorrelated with the average change in price at other supermarkets.

In our base specification, we include the tax change (in cents per pack) over the following month to capture stockpiling behavior. Our estimate of $\beta_{1}$ captures the idiosyncratic change in purchases within-four weeks of an anticipated increase in excise taxes. Motivated by figures 3 and 4 , we interact the tax change over the subsequent month with an indicator variable for discount cigarettes to test whether stockpiling of discount and premium cigarettes differs. In addition, we further interact this variable with a store's proximity to Indiana, the lowest-tax jurisdiction in our sample, to examine whether stockpiling differs with border-proximity. Finally, 
we interact the tax change with the demographic characteristics of the store's clientele.

We also include a measure of the strength of the incentive to travel to a lower-tax jurisdiction. As a proxy, we calculate the difference in the tax at a particular store and the closest neighboring state $\left(\operatorname{dtax}_{j t}\right)$ and divide it by the straight-line distance to that state's border $\left(\right.$ dist $\left._{j}\right) .{ }^{9}$ This proxy incorporates the fact that the tax differential and border proximity work in opposite directions. As the tax differential rises (e.g., tax in Cook county rises) or the distance to the border falls, consumers will be more likely to border-cross, and we would expect cigarette sales to fall. Since the incentive to travel to low-tax jurisdictions also depends on how many cigarettes a smoker regularly consumes, we further interact our proxies for stockpiling with an indicator variable for sales by the carton.

Table 4 presents the results of our regression. We estimate a cigarette price elasticity between -0.35 to -0.40 , falling within the range of estimates from the previous literature, ranging from -0.14 to -1.23 (Chaloupka and Warner, 2000). In specifications (5) and (6), we interact price with and indicator variable for discount cigarettes - the point estimate for discount cigarettes is positive with a p-value of 0.106 , suggesting that demand for discount cigarette may be less elastic than demand for premium cigarettes.

We find evidence of stockpiling prior to tax increases - in our base specification, we estimate that a one-cent increase in taxes is associated with 1.4 percent increase in sales for the fourweeks prior to the tax change. Consistent with our results from the event study analysis of the tax increase in July 1993, we find that stockpiling is entirely driven by sales of discount cigarettes. We estimate that a one cent increase in taxes is associated with approximately four percent increase in sales of discount cigarettes one month prior to the tax change. Stockpiling increases in magnitude with distance from Indiana - the nearest jurisdiction with substantially lower taxes for many smokers. ${ }^{10}$ Across specifications (3) through (6), we estimate that in the month before a ten-cent tax change, sales of discount cigarettes rise between 40 and 45 percent at a store located at mean distance from the Indiana border (27.5 miles). Our results also suggest that, even for discount cigarettes, very little stockpiling occurs within 8-10 miles of the

\footnotetext{
${ }^{9}$ We use a store's closest neighboring state as the point of comparison. For all stores, the neighboring states of Wisconsin and Indiana represent the greatest absolute tax savings. Consumers purchasing within Cook County (or alternatively, within Chicago) may prefer to travel a shorter distance (e.g. just outside of the county or city but not outside of Illinois) to avoid the county and city taxes, but not the state taxes. For these consumers, we also calculated the location that represented the greatest tax savings per mile traveled and used that as the point of comparison for an alternative measure of the border crossing incentive. This alternative measure is highly correlated $(\mathrm{r}=0.89)$ with our more simple comparison to the closest neighboring state. Furthermore, the use of the alternative measure does not substantially change our results.

${ }^{10}$ Although some smokers may travel to Wisconsin as well, the tax differential is substantially smaller. In fact, prior to the July 1993 tax increase, the per-pack excise tax in Wisconsin was eight cents per pack higher than that in Illinois. The per-pack excise tax in Indiana, on the other hand, was twelve cents lower prior to the tax change.
} 
Indiana border.

When we interact the tax change over the subsequent month with demographics, we find that stockpiling is negatively correlated with the proportion of minority customers, although the effect is quite modest. We estimate that a one-standard deviation in the proportion of nonminority customers is associated with six percent higher sales in the month before a ten-cent tax change. We do not find that other demographics are significantly correlated with stockpiling. Furthermore, we do not find that the inclusion of the demographic variables substantively affects the estimates of our other coefficients.

We find mixed evidence that consumers travel from high-tax to low-tax jurisdictions. In our base regression, we estimate a negative, but imprecisely estimated coefficient on our proxy for the strength of the incentive to cross to a lower tax jurisdiction. Since the incentive to border-cross is greater for heavy smokers than light smokers, and smoking intensity is likely correlated with purchasing by the carton rather than the pack, we test whether carton-level sales respond more to border proximity and tax differential than pack-level sales. When we estimate the coefficient on the interaction term, we find that that the incentive to border cross affects sales by the carton exclusively. For a store five miles from the Indiana border, facing the average Illinois - Indiana tax differential during the period ( $\sim 24$ cents per pack), we estimate that carton sales are approximately 44 percent lower than carton sales at store of mean distance from the Indiana border. We do not find a similar decline in sales of individual packs.

To examine substitution between premium and discount cigarettes, calculate the market share of discount cigarettes at each store. We regress discount cigarette market share on a similar set of variables to those in the previous regression, replacing the pack price with the appropriate cigarette tax for the store measured in cents per pack. Again, we include store fixed effects as well as a quartic time trend. The coefficients on the excise tax and interactions with demographics and distance capture long-run changes in market share after controlling for the quartic time trend, and the coefficients on the dummy variables for the immediate months preceding and following the tax change reflect short-run changes in market share.

Our stylized theoretical model makes several predictions about tax-induced substitution between quality-tiers. Absent addiction, we should expect consumers to shift from discount to premium cigarettes following a tax increase - an increase in per-unit taxes reduces the relative price differential between premium and discount cigarettes. Although consumer will stockpile, they will stockpile whatever cigarettes they consumed in the pre-tax period. With addiction, though, consumer may shift between different quality-tiers to help smooth their adjustment to 
high cigarette taxes. If the disutility of reducing consumption is sufficiently high, the model predicts that even individuals who smoke premium cigarettes in the pre-tax period may stockpile discount cigarettes and may shift consumption to discount cigarettes for a time following a tax increase to help smooth the transition to higher taxes.

Our results in Table 5 are consistent with these predictions. Across all five specifications, we find that cigarette taxes are negatively correlated with the market share of discount cigarettes. A ten cent increase in cigarette taxes is associated with a percentage point reduction in discount cigarette market share. This effect declines as the percent of a store's customers that are minority or over 60 years of age increases. These smokers may permanently substitute away from premium brands in favor of cheaper discount cigarettes. In the short-run, though, we find evidence consistent with consumer addiction. In the month preceding a tax change, we find that consumers tend to stockpile discount cigarettes - a ten cent increase in cigarette taxes is associated with a 4.5 percentage point increase in the market share of discount cigarettes. This result is consistent with the substantial stockpiling of cigarettes observed in the event study analysis and the panel regressions in Table 4. Furthermore, we also see a shift towards discount cigarettes for a time following a tax change. In the immediate month following the tax increase, the discount market share remains elevated - a ten cent tax increase is associated with approximately a 2.4 percentage point increase in the discount market share.

These results confirm the evidence from the event study in the previous section that consumers do engage in border-crossing due to differential taxes across jurisdictions and do in fact stockpile in anticipation of tax increases. The consumers most likely to travel are the heavy smokers, who consume large quantities (cartons) of cigarettes. In the short-run, stockpiling behavior varies by demographic with higher-educated areas stockpiling in anticipation of a tax increase. Furthermore, we find some evidence consistent with substitution from premium to discount cigarettes in the month after the tax change, although over the longer-run the share of discount cigarettes is negatively correlated with the tax increase. These results that consumers' short- and long-run response to a tax increase vary for different segments of the population, depending on brand preferences, demographics and location.

\subsection{Tax Incidence}

Finally, we examine the incidence of cigarette excise taxes. The results in the previous section suggest that smokers of premium and discount cigarettes and smokers located nearby and far from borders respond very differently to tax increases. In addition, we found suggestive evidence 
that demand for discount brands was less elastic than demand for premium brands. We test to see whether these heterogeneous responses translate into differences in excise tax pass-through. For taxes motivated by non-fiscal considerations like "sin" taxes, incidence plays a clear role in regulatory efficacy. If the burden of taxes falls primarily on producers, the effect of tax on smoking intensity may be lessened.

As Poterba (1996) points out, there has been limited empirical work on the incidence of cigarette excise taxes and consumer goods more generally. Keeler, et al. (1996) use aggregate state-level data from 1960 to 1990 and find that state taxes are more than passed on to consumers. A one-cent tax increase is associated with a price increase of 1.11 cents. More recently, Doyle and Samphantharak (2008) have examined the effects of a gas tax moratorium on retail gasoline prices and find that short-run pass-through estimates are smaller near state borders. Other studies have also analyzed pass-through in the retail market for gasoline and alcohol (Chouinard and Perloff (2004, 2007); Marion and Muehlegger (2010); Kenkel (2005) Alm, et al. (2009)).

Our analysis contributes to this research in two important ways. First, we exploit our ability to observe UPC-level prices to estimate pass-through for different classes of cigarettes (premium vs. discount cigarettes and sales by the carton or pack). To our knowledge, ours is the first paper to estimate pass-through for different classes of cigarettes and one of very few to examine tax incidence at the product-level. Consequently, our estimates inform whether differential rates of substitution across and between different quality-tiers lead to meaningful differences in tax incidence. Second, our analysis informs the growing literature empirically examining tax incidence near jurisdictional boundaries. Similar to Doyle and Samphantharak (2008), we empirically test whether greater demand elasticity near low-tax borders leads to a meaningful reduction in pass-through rates. Our results from the previous section predict that this effect should vary for different classes of cigarettes - border-proximity disproportionately affects sales of cigarettes sold by the carton, suggesting that heavy smokers of these cigarettes are more willing to travel to avoid cigarette taxes. Consequently, we examine whether pass-through is lower near low-tax borders, and is particularly low for premium cigarettes sold by the carton for which border-crossing is greatest.

We estimate cigarette tax incidence in a straightforward fashion. We assume that the taxinclusive price for UPC $u$ in category $k$ and store $j$ at time $t$ is a function of the relevant excise tax, the excise tax interacted with our proxy for the incentive to border-cross (the tax differential to the neighboring state divided by the distance to the state), class-specific linear time trends 
and UPC-store fixed effects:

$$
\begin{aligned}
\text { Tax Inclusive Price }_{u j t}= & \alpha_{u j}+\sum_{k} \beta_{k} \text { ExciseTax }_{j t} \\
& +\gamma * \text { ExciseTax }_{j t} *\left(\operatorname{dtax}_{j t} / \text { dist }_{j}\right) \\
& +\eta \text { Carton }_{u} * \operatorname{ExciseTax~}_{j t} *\left(\operatorname{dtax}_{j t} / \operatorname{dist}_{j}\right) \\
& +\delta_{k} * t+\epsilon_{u j t} .
\end{aligned}
$$

Rather than estimate the equation in levels, we first-difference all of the variables (dropping the time-invariant UPC-store fixed effects) and estimate tax incidence off of retail price changes contemporaneous with the tax increase. By first-differencing, we do not misattribute the price effects of long-term shifts of supply and demand as changes in tax incidence. We consider four cigarette classes (branded vs. discount, pack vs. carton) denoted by $k$ and separately estimate pass-through for each class of cigarette. Consequently, the equation we estimate is

$$
\begin{aligned}
\Delta \text { Tax Inclusive Price }_{u j t}= & \sum_{k} \beta \Delta \text { ExciseTax }_{j t} \\
& +\gamma \Delta \text { ExciseTax }_{j t} *\left(\text { dtax }_{j t} / \text { dist }_{j}\right) \\
& +\eta \text { Carton }_{u} * \Delta \operatorname{ExciseTax}_{j t} *\left(\text { dtax }_{j t} / \text { dist }_{j}\right) \\
& +\delta_{k}+\nu_{u j t} .
\end{aligned}
$$

Table 6 presents our results. In column 1, we estimate a common pass-through coefficient for all cigarettes and estimate that consumers bear approximately 52 percent of cigarette excise taxes. In column 2 , we include interaction terms for carton sales and discount sales. Consistent with our empirical results from the panel regressions, we find that pass-through for cartons is 21 percentage points lower than pass-through for cigarettes sold by the pack. Moreover, we find that pass-through for discount cigarettes is 6 percentage points higher than that for premium cigarettes consistent with demand for discount cigarettes being more price-inelastic than demand for premium cigarettes. In column 3, we separately estimate incidence for each class of cigarettes and find a similar pattern. Pass-through for products sold by the pack is higher than pass-through for cartons and a greater fraction of cigarette taxes are borne by smokers of discount cigarettes than premium cigarettes. Estimates of tax pass-through vary from 39 percent for premium cigarettes sold by the carton to 64 percent for discount cigarettes sold by the pack.

In column 4, we include two interaction terms to study whether proximity to low-tax borders 
is correlated with excise tax pass-through. The first term interacts the excise tax with our proxy for the incentive to border cross (the tax differential to the neighboring state divided by the distance to the state). This term allows pass-through to vary for stores close-to and far-from borders as well as over time as the excise tax-differentials between Illinois, Wisconsin and Indiana change. Second, we include an additional interaction term specific to premium cigarettes sold by the carton. This term allows us to test for an especially large reduction in pass-through for the class of cigarettes for which we observe the most border crossing.

Our results are entirely consistent with our empirical findings of consumer behavior. We estimate that tax pass-through falls as the incentive to cross to a low-tax jurisdiction increases (either through rising tax differentials or increased proximity). This is consistent with incidence theory if demand near low-tax jurisdictions is more tax elastic. Furthermore, we find that this effect is especially strong for cigarettes sold by the carton, for which border-crossing is greatest. At a store five miles from the Indiana border, our estimates suggest that pass-through for cartons is approximately 11 percentage points lower than at a store in the interior of the state. Pass-through for cigarettes sold by the pack is approximately 4 percentage points lower. The differential effect of border proximity accounts for approximately half of the variation in pass-through between cigarettes sold by the carton and cigarettes sold by the pack.

Finally, the nature of our data allows us to consider one additional analysis. Discussions of tax incidence often make an implicit assumption that pass-through is relatively uniform for all brands of a particular good (such as cigarettes). In our particular context, we can estimate pass-through rates specific to each UPC-store. We examine how much of the variation in UPCstore level pass-through rates is explained by class- or UPC- dummy variables and find that much of the variation in pass-through rates occurs at the class-level. ${ }^{11}$ Between-class variation accounts for approximately 44 percent of the variation in pass-through rates. Within-class but between-UPC variation accounts for an additional 8 percent of the variation in pass-through rates. The remainder is variation in within-UPC variation in pass-through rates at different stores. This suggests that much of the variation in pass-through rates can be captured by relatively parsimonious product characteristics.

\footnotetext{
${ }^{11}$ For the analysis, we exclude UPCs appearing infrequently in the data. We limit our sample to UPCs appearing in at least one-quarter of the stores in our sample and with positive sales for at least twenty-six weeks. As in the analyses above, we include UPC-store fixed effects. We also include UPC-specific time trends.
} 


\section{Conclusion}

Consumers can adapt and respond to tax changes in various ways in the short- and long-run that may undermine the intent of the tax. In this paper, we identify four different margins by which consumers may alter their behavior: (1) reducing consumption, (2) stockpiling prior to a tax change, (3) substituting purchases away from high-tax jurisdictions to low-tax jurisdictions, and (4) substituting between high-price and low-price products.

Using a rich panel of cigarette sales at 85 locations of a Dominick's Finer Foods in the Chicago area, we apply two distinct empirical approaches to examine consumers' response to changes in cigarette excise taxes. Our first approach exploits a discrete increase in Illinois' state cigarette tax that increased the per-pack excise tax approximately 46 percent in July 1993. We apply an event study approach to examine consumers' short-run response to tax changes. Then we extend our analysis to exploit a long panel of state and local tax changes, as well as heterogeneity in store location and demographics.

We estimate price elasticities of approximately -0.4 , consistent with other estimates from the literature. In addition, we find evidence of all three types of cigarette tax avoidance: stockpiling, border-crossing, and shifting from higher to lower-quality cigarettes. Interestingly, we find substantial variation in how smokers of different cigarettes choose to avoid cigarette taxes.

We find that stockpiling differs markedly by quality-tier. For discount cigarettes, we find evidence of substantial stockpiling. In the month prior to a ten-cent tax increase, we estimate that discount cigarette sales increase forty to forty-five percent. We do not find evidence of stockpiling for premium cigarettes.

We find some evidence that consumers substitute between quality-tiers in the short-run in response to tax changes. In the month after a tax increase, we find that the market share of discount cigarettes rises, consistent with consumers substituting to lower-cost cigarettes to help smooth their reduction in consumption. Over the longer term, we find that taxes are positively correlated with premium cigarette market share, except at stores with relatively higher proportion of minority customers or customers over age sixty. While most smokers who continue to smoke absorb the additional taxes, customers at these stores appear to shift from premium cigarettes to less expensive discount cigarettes to offset the increase in taxes.

Finally, we find that stores closer to lower-tax jurisdictions face greater reductions in sales following tax increases. We estimate that the effect is almost entirely driven by sales of premium cartons and is consistent with heavy smokers traveling to nearby lower-tax jurisdictions to evade higher in-state excise taxes. For the typical store, located 27.5 miles from the Indiana border, 
we estimate that a ten cent increase in the Illinois state tax is associated with a seven percent reduction in carton sales. In contrast, we estimate that a similar tax increase is associated with a thirty two percent reduction in carton sales for a store 5 miles from the Indiana border.

Importantly for policy, we find that these difference in smoker response lead to meaningful differences in excise tax incidence. Consistent with incidence theory, we find that pass-through increases for more price-inelastic brands and declines in situations where consumers can easily avoid state, county and local cigarette taxes. We estimate that pass-through is greater for discounted brands for which demand is more inelastic. In addition, we find that pass-through falls for all cigarettes near low-tax borders, but the effect is most pronounced for cigarettes sold by the carton, for which cross-border avoidance is greatest. We estimate that cross-border avoidance causes pass-through to decline by approximately 11 percentage points for cartons when sold near to low-tax borders.

Our results inform the public policy implications of tax increases, especially for "sin" taxes with non-fiscal motives. For these taxes, consumer avoidance directly undermines policy objectives. We find that consumer behavior in anticipation and following a tax increase vary by the intensity of consumption (heavy vs. light smokers), proximity to the border, and by demographics (such as age and race). In addition, our results have important implications for tax policy evaluation. Our results suggest that short-run changes in smoking are likely to be misrepresentative of long-run changes in behavior. In the short-run, stockpiling and substitution to low-cost cigarettes allow consumers to partially mitigate the effects of a tax increase. Furthermore, the behavior of consumers close to jurisdictional boundaries are unlikely to be similar to the behavior of consumers who do not have access to lower-tax alternatives. Near these boundaries, consumers can avoid tax increases. Finally "sin" taxes are passed less-fully onto consumers near the borders of lower-tax jurisdictions, potentially limiting the impact on consumers who continue to purchase within the high-tax jurisdiction. Any tax intervention meant to either directly or indirectly discourage consumption should take these consumer responses into account. 


\section{References}

[1] Adda, J., Cornaglia, F. (2006). "Taxes, Cigarette Consumption and Smoking Intensity," American Economic Review, 96, 1013-1028.

[2] Alm, J., Sennoga, E., Skidmore, M. (2009). "Perfect Competition, Urbanization, and Tax Incidence in the Retail Gasoline Market," Economic Inquiry, 47, 118-134.

[3] Baltagi, B.H., Goel, R.K. (2000). "Quasi-Experimental Price Elasticity of Liquor Demand in the United States: 1960-83," American Journal of Agricultural Economics, 72, 451-454.

[4] Baltagi, B.H., Griffin, J.M. (1995). "A Dynamic Demand Model for Liquor: The Case for Pooling," The Review of Economics and Statistics, 77, 545-553.

[5] Beard, T., Gant, P., Saba, R. (1997). "Border-Crossing Sales, Tax Avoidance, and State Tax Policies: An Application to Alcohol," Southern Economic Journal, 64, 293-306.

[6] Chaloupka, F., Warner, K.E. (2000). "The Economics of Smoking," Handbook of Health Economics, Elsevier Science, North Holland.

[7] Chiou, L.. Muehlegger, E. (2008). "Crossing the Line: Direct Estimation of Cross-Border Cigarette Sales and the Effect on Tax Revenue," The B.E. Journal of Economic Analysis and Policy (Contributions), 8, Article 48.

[8] Chouinard, H., Perloff, J.M. (2004). "Incidence of Ferderal and State Gasoline Taxes," Economics Letters, 83, 55-60.

[9] Chouinard, H., Perloff, J.M.(2007). "Gasoline Price Differences: Taxes, Pollution Regulators, Mergers, Market Power, and Market Condition," The B.E. Journal of Economic Analysis and Policy, 7, Article 8.

[10] Coats, M. (1995). "A Note on Estimating Cross-Border Effects of State Cigarette Taxes," National Tax Journal, 48, 573-584.

[11] Crawford, I., Tanner, S. (1995). "Bringing It All Back Home: Alcohol Taxation and CrossBorder Shopping," Fiscal Studies, 16, 94-114.

[12] DeCicca, P., Kenkel, D., Mathios, A., Shin, Y., Lim, Y. (2006). "Youth Smoking, Cigarette Prices, and Anti-smoking Sentiment", Health Economics, 17, 733-749.

[13] Doyle, J., Samphantharak, K. (2008). " $\$ 2.00$ Gas! Studying the Effects of a Gas Tax Moratorium," Journal of Public Economics, 92. 869-884.

[14] Ellison, G., Ellison, S.F. (2007). "Internet Retail Demand: Taxes, Geography, and OnlineOffline Competition," Massachusetts Institute of Technology, Department of Economics, working paper.

[15] Emery, S., White, M., Gilpin, E., Pierce, J. (2002). "Was There Significant Tax Evasion After the 199950 Cent Per Pack Cigarette Tax Increase in California," Tobacco Control, $11,130-134$.

[16] Goolsbee, A. (2000). "In a World Without Borders: The Impact of Taxes on Internet Commerce," The Quarterly Journal of Economics, Vol. 115, no. 2, pp. 561-576.

[17] Goolsbee, A., Lovenheim, M.F., Slemrod, J. (2007). "Playing with Fire: Cigarettes, Taxes and Competition from the Internet." American Economic Journal: Economic Policy, forthcoming.

[18] Gruber, J., Sen, A., Stabile, M. (2003). "Estimating Price Elasticities When There Is Smuggling: The Sensitivity of Smoking to Price In Canada," Journal of Health Economics, $22,821-842$.

[19] Hausman, J. (1997). "Valuation of New Goods Under Perfect and Imperfect Competition," ed. T. Bresnahan and R. Gordon, The Economics of New Goods, 1997. 
[20] Hyland, A., Bauer, J.E., Li, Q., Abrams, S.M., Higbee, C., Peppone, L., Cummings, K.M. (2005). "Higher Cigarette Prices Influence Cigarette Purchase Patterns," Tobacco Control, 14, 86-92.

[21] Keeler, T.E., Hu, T., Barnett, P.G., Manning, W.G., Sung, H. (1996). "Do Cigarette Producers Price-discriminate by State? An Empirical Analysis of Local Cigarette Pricing and Taxation," Journal of Health Economics, 15, 499-512.

[22] Kenkel, D. (2005). "Are Alcohol Tax Hikes Fully Passed through to Prices? Evidence from Alaska," American Economic Review Papers and Proceedings, 95, 273-277.

[23] Lovenheim, M.F. (2008). "How Far to the Border?: The Extent and Impact of Cross-Border Casual Cigarette Smuggling," National Tax Journal, 61, 7-33.

[24] Manuszak, M., Moul, C. (2006). "How Far for a Buck? Tax Differences and the Location of Retail Gasoline Activity in Southeast Chicagoland," Review of Economics and Statistics, forthcoming.

[25] Marion, J., Muehlegger, E. (2010). "Tax Incidence and Supply Conditions," Harvard Kennedy School working paper.

[26] Nevo, A. (2001). "Measuring Market Power in the Ready-to-Eat Cereal Industry," Econometrica, 69, 307-342.

[27] Poterba, J.M. (1996). "Retail Price Reactions to Changes in State and Local Sales Taxes," National Tax Journal, 49, 165-176.

[28] Stehr, M. (2005). "Cigarette Tax Avoidance and Evasion," Journal of Health Economics, 24, 277-297.

[29] Stehr, M. (2007). "The Effect of Sunday Sales Bans and Excise Taxes on Drinking and Cross Border Shopping for Alcoholic Beverages," National Tax Journal, 60, 85-105.

[30] Sung, H., Hu, T., Keeler, T. (1994). "Cigarette Taxation and Demand: An Empirical Model," Contemporary Economic Policy, 12, 91-100.

[31] The Tax Burden on Tobacco Historical Compilation (2007), 42, electronic.

[32] Thursby, J., Thursby, M. (2000). "Interstate Cigarette Bootlegging: Extent, Revenue Losses, and Effects of Federal Intervention," National Tax Journal, 53 (1), 59-77.

[33] Yurekli, A., Zhang, P. (2000), "The Impact of Clean Indoor Air Laws and Cigarette Smuggling on Demand for Cigarettes: An Empirical Model," Health Economics, 9, 159-170. 
Figure 1: Cigarette Excise Tax (cents/pack)

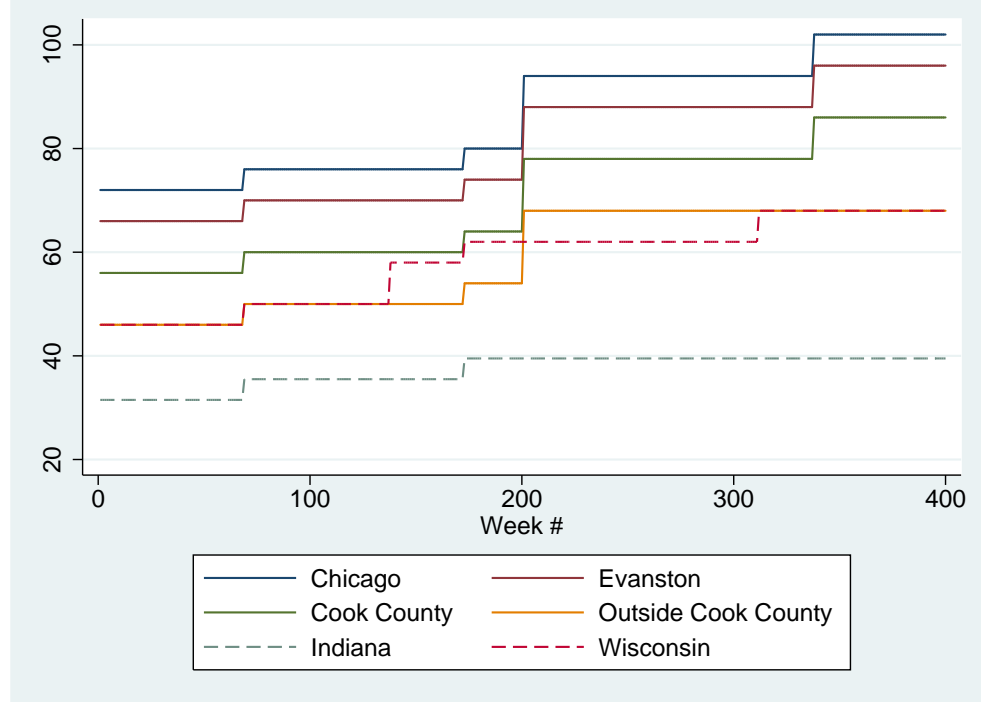

Figure 2: Cigarette Excise Tax, relative to Wisconsin (cents/pack)

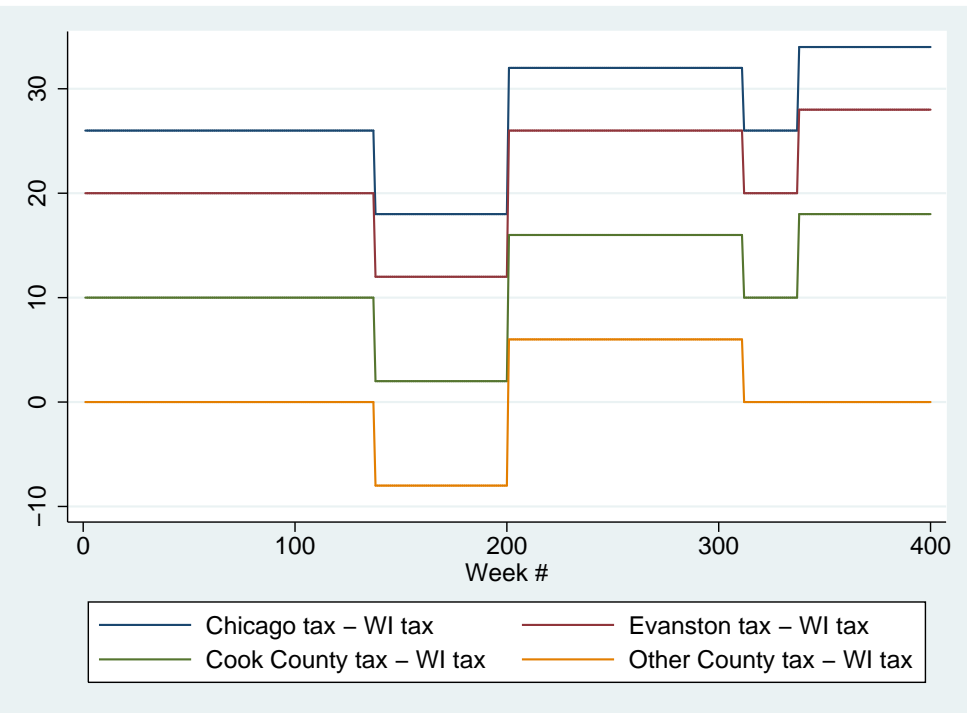


Figure 3:

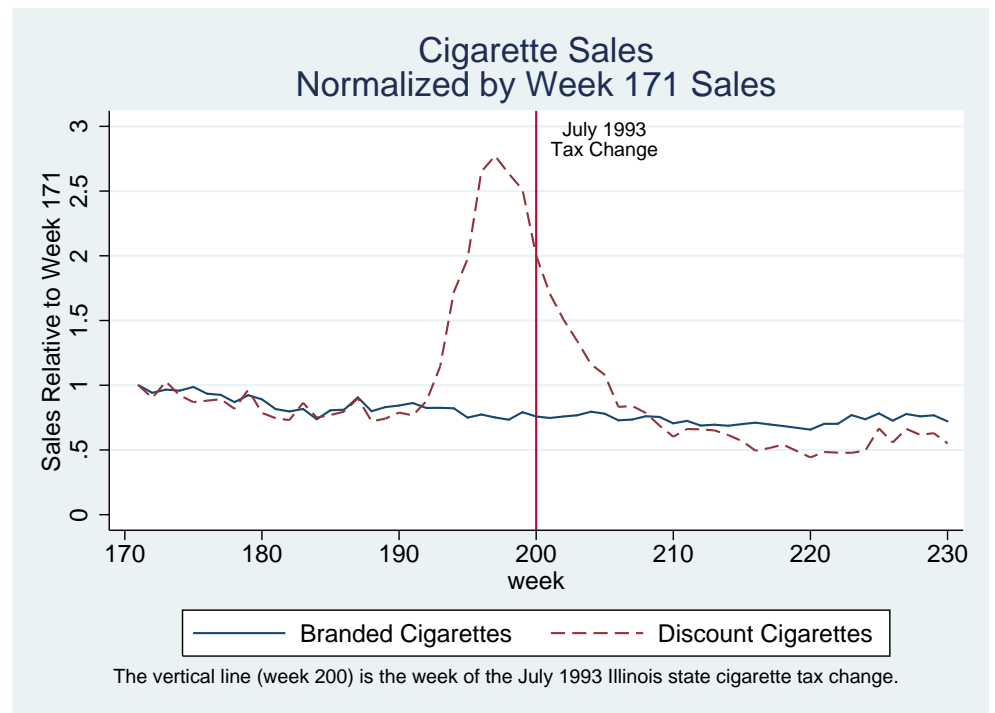

Figure 4:

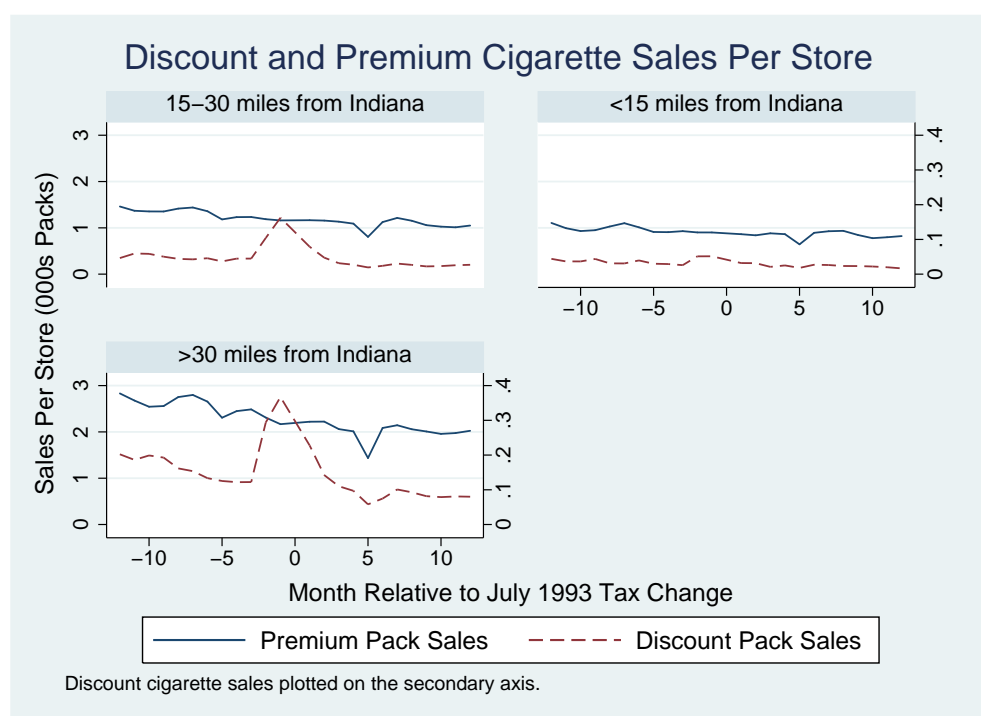


Table 1: Summary Statistics

\begin{tabular}{lccccc}
\hline \hline & Mean & Std Dev & Min & Max & Observations \\
\hline Packs Sold & 393.4 & 294.5 & 1 & 1917 & 24221 \\
Packs Sold by the Carton & 191.0 & 184.0 & 0 & 1440 & 24221 \\
Discount Packs Sold & 17.5 & 28.2 & 0 & 571 & 24221 \\
Price Per Pack (\$/pack) & 2.32 & 0.23 & 1.72 & 4.21 & 24221 \\
Price Per Pack - Sales by the Carton (\$/pack) & 2.09 & 0.14 & 1.67 & 2.57 & 22372 \\
Price Per Pack - Discount Sales (\$/pack) & 2.03 & 0.25 & 1.30 & 6.81 & 18497 \\
Per Pack Excise Tax (cpp) & 73.8 & 13.5 & 50 & 102 & 24221 \\
Excise Tax Relative to Indiana (cpp) & 35.3 & 12.6 & 14.5 & 62.5 & 24221 \\
Excise Tax Relative to Wisconsin (cpp) & 12.2 & 11.4 & -8 & 34 & 24221 \\
Distance to IN (miles) & 27.6 & 11.2 & 2.02 & 56.6 & 24221 \\
Distance to WI (miles) & 42.7 & 11.9 & 20.2 & 71.2 & 24221 \\
Log(Median Household Income) & 10.6 & 0.28 & 9.87 & 11.2 & 23414 \\
Percent of Customers Below Poverty Line & 0.056 & 0.043 & 0.014 & 0.21 & 23414 \\
Percent of Customers College-educated & 0.23 & 0.11 & 0.050 & 0.53 & 23414 \\
Percent of Customers Over Age 60 & 0.17 & 0.062 & 0.058 & 0.31 & 23414 \\
Percent of Minority Customers & 0.15 & 0.17 & 0.024 & 1.00 & 23414 \\
\hline
\end{tabular}

Note: Summary statistics based on UPC-level data aggregated to the store* week level.

Prices for carton and discount cigarettes are conditional on positive sales. 
Table 2: The Effect of the June 1993 Illinois Tax Increase

\begin{tabular}{|c|c|c|c|}
\hline & $\begin{array}{c}(1) \\
\text { total }\end{array}$ & $\begin{array}{c}(2) \\
\text { premium } \\
\end{array}$ & $\begin{array}{c}(3) \\
\text { discount }\end{array}$ \\
\hline month 3 & $\begin{array}{l}0.0604^{*} \\
(0.0322)\end{array}$ & $\begin{array}{c}0.0356 \\
(0.0234)\end{array}$ & $\begin{array}{c}0.0821 \\
(0.0553)\end{array}$ \\
\hline month 4 & $\begin{array}{c}0.250^{* * *} \\
(0.0513)\end{array}$ & $\begin{array}{l}-0.0227 \\
(0.0209)\end{array}$ & $\begin{array}{c}0.800^{* * * *} \\
(0.0879)\end{array}$ \\
\hline month 5 (tax increase) & $\begin{array}{c}0.394^{* * *} \\
(0.0626)\end{array}$ & $\begin{array}{c}-0.0321 \\
(0.0311)\end{array}$ & $\begin{array}{c}1.223^{* * *} \\
(0.0983)\end{array}$ \\
\hline month 6 & $\begin{array}{c}0.168^{* * *} \\
(0.0582)\end{array}$ & $\begin{array}{c}0.00653 \\
(0.0441)\end{array}$ & $\begin{array}{c}0.609^{* * *} \\
(0.101)\end{array}$ \\
\hline month 7 & $\begin{array}{c}-0.0283 \\
(0.0544)\end{array}$ & $\begin{array}{c}0.000182 \\
(0.0378)\end{array}$ & $\begin{array}{c}0.152 \\
(0.0917)\end{array}$ \\
\hline month 8 & $\begin{array}{c}-0.0481 \\
(0.0547)\end{array}$ & $\begin{array}{c}0.0901 \\
(0.0572)\end{array}$ & $\begin{array}{c}-0.110 \\
(0.0900)\end{array}$ \\
\hline months 9 and 10 & $\begin{array}{c}-0.165^{* * *} \\
(0.0590) \\
\end{array}$ & $\begin{array}{c}0.0636 \\
(0.0609) \\
\end{array}$ & $\begin{array}{c}-0.354^{* * *} \\
(0.0922)\end{array}$ \\
\hline Observations & 6165 & 3363 & 2802 \\
\hline
\end{tabular}

The dependent variable is the log of sales over a ten-month window surrounding the June 1993 increase in the Illinois excise tax. The tax increase occurred at the end of month 5 . The baseline period is months 1 and 2, three months prior to the tax increase when we expect no behavioral change in response to the future tax. All specifications include store fixed effects. Robust Standard Errors clustered at the store level. ${ }^{*} p<0.10,{ }^{* *} p<0.05,{ }^{* * *} p<0.01$. 
Table 3: The Effect of the June 1993 Illinois Tax Change on Total, Premium and Discount Sales, by location

\begin{tabular}{|c|c|c|c|c|c|c|}
\hline & $\begin{array}{c}(1) \\
\text { near }\end{array}$ & $\begin{array}{l}(2) \\
\text { far } \\
\end{array}$ & $\begin{array}{l}(3) \\
\text { premium: near }\end{array}$ & $\begin{array}{c}(4) \\
\text { premium: far }\end{array}$ & $\begin{array}{c}(5) \\
\text { discount: near }\end{array}$ & $\begin{array}{c}(6) \\
\text { discount: far }\end{array}$ \\
\hline month 3 & $\begin{array}{c}0.125 \\
(0.0767)\end{array}$ & $\begin{array}{c}0.0454 \\
(0.0357)\end{array}$ & $\begin{array}{c}0.0379 \\
(0.0694)\end{array}$ & $\begin{array}{c}0.0349 \\
(0.0229)\end{array}$ & $\begin{array}{l}0.0546 \\
(0.127)\end{array}$ & $\begin{array}{c}0.0914 \\
(0.0623)\end{array}$ \\
\hline month 4 & $\begin{array}{c}0.102 \\
(0.108)\end{array}$ & $\begin{array}{c}0.287^{* * *} \\
(0.0577)\end{array}$ & $\begin{array}{l}-0.0720 \\
(0.0607)\end{array}$ & $\begin{array}{r}-0.00828 \\
(0.0202)\end{array}$ & $\begin{array}{c}0.529 * * * \\
(0.153)\end{array}$ & $\begin{array}{c}0.859^{* * *} \\
(0.100)\end{array}$ \\
\hline month 5 (tax increase) & $\begin{array}{c}0.142 \\
(0.135)\end{array}$ & $\begin{array}{c}0.457^{* * *} \\
(0.0685)\end{array}$ & $\begin{array}{r}-0.00922 \\
(0.0632)\end{array}$ & $\begin{array}{c}-0.0382 \\
(0.0360)\end{array}$ & $\begin{array}{c}0.642^{* * *} \\
(0.222)\end{array}$ & $\begin{array}{c}1.345^{* * *} \\
(0.104)\end{array}$ \\
\hline month 6 & $\begin{array}{c}-0.0474 \\
(0.110)\end{array}$ & $\begin{array}{c}0.223^{* * *} \\
(0.0658)\end{array}$ & $\begin{array}{l}0.0227 \\
(0.139)\end{array}$ & $\begin{array}{l}0.00237 \\
(0.0417)\end{array}$ & $\begin{array}{l}0.0130 \\
(0.151)\end{array}$ & $\begin{array}{c}0.735^{* * *} \\
(0.112)\end{array}$ \\
\hline month 7 & $\begin{array}{l}-0.186 \\
(0.143)\end{array}$ & $\begin{array}{c}0.0146 \\
(0.0566)\end{array}$ & $\begin{array}{l}0.0329 \\
(0.118)\end{array}$ & $\begin{array}{r}-0.00878 \\
(0.0358)\end{array}$ & $\begin{array}{r}-0.0228 \\
(0.187)\end{array}$ & $\begin{array}{l}0.188^{*} \\
(0.104)\end{array}$ \\
\hline month 8 & $\begin{array}{c}-0.00740 \\
(0.112)\end{array}$ & $\begin{array}{l}-0.0592 \\
(0.0628)\end{array}$ & $\begin{array}{l}0.301^{*} \\
(0.158)\end{array}$ & $\begin{array}{c}0.0291 \\
(0.0569)\end{array}$ & $\begin{array}{c}-0.329^{*} \\
(0.170)\end{array}$ & $\begin{array}{c}-0.0626 \\
(0.102)\end{array}$ \\
\hline months 9 and 10 & $\begin{array}{c}-0.0169 \\
(0.148) \\
\end{array}$ & $\begin{array}{c}-0.203^{* * *} \\
(0.0639) \\
\end{array}$ & $\begin{array}{c}0.285 \\
(0.172) \\
\end{array}$ & $\begin{array}{l}0.00154 \\
(0.0602) \\
\end{array}$ & $\begin{array}{l}-0.286 \\
(0.190) \\
\end{array}$ & $\begin{array}{c}-0.371^{* * *} \\
(0.104) \\
\end{array}$ \\
\hline Observations & 1254 & 4911 & 747 & 2616 & 507 & 2295 \\
\hline
\end{tabular}

The sample is split for premium and discount cigarettes as well as for stores located near (within 20 miles) and far from Indiana (the nearest jurisdiction with substantially lower taxes. The dependent variable is the log of sales over a ten-month window surrounding the June 1993 increase in the Illinois excise tax. The tax increase occurred at the end of month 5 . The baseline period is months 1 and 2, three months prior to the tax increase when we expect no behavioral change in response to the future tax. All specifications include store fixed effects. Robust Standard Errors clustered at the store level. ${ }^{*} p<0.10,{ }^{* *} p<0.05,{ }^{* * *} p<0.01$. 
Table 4: Consumer Response to Excise Tax Changes

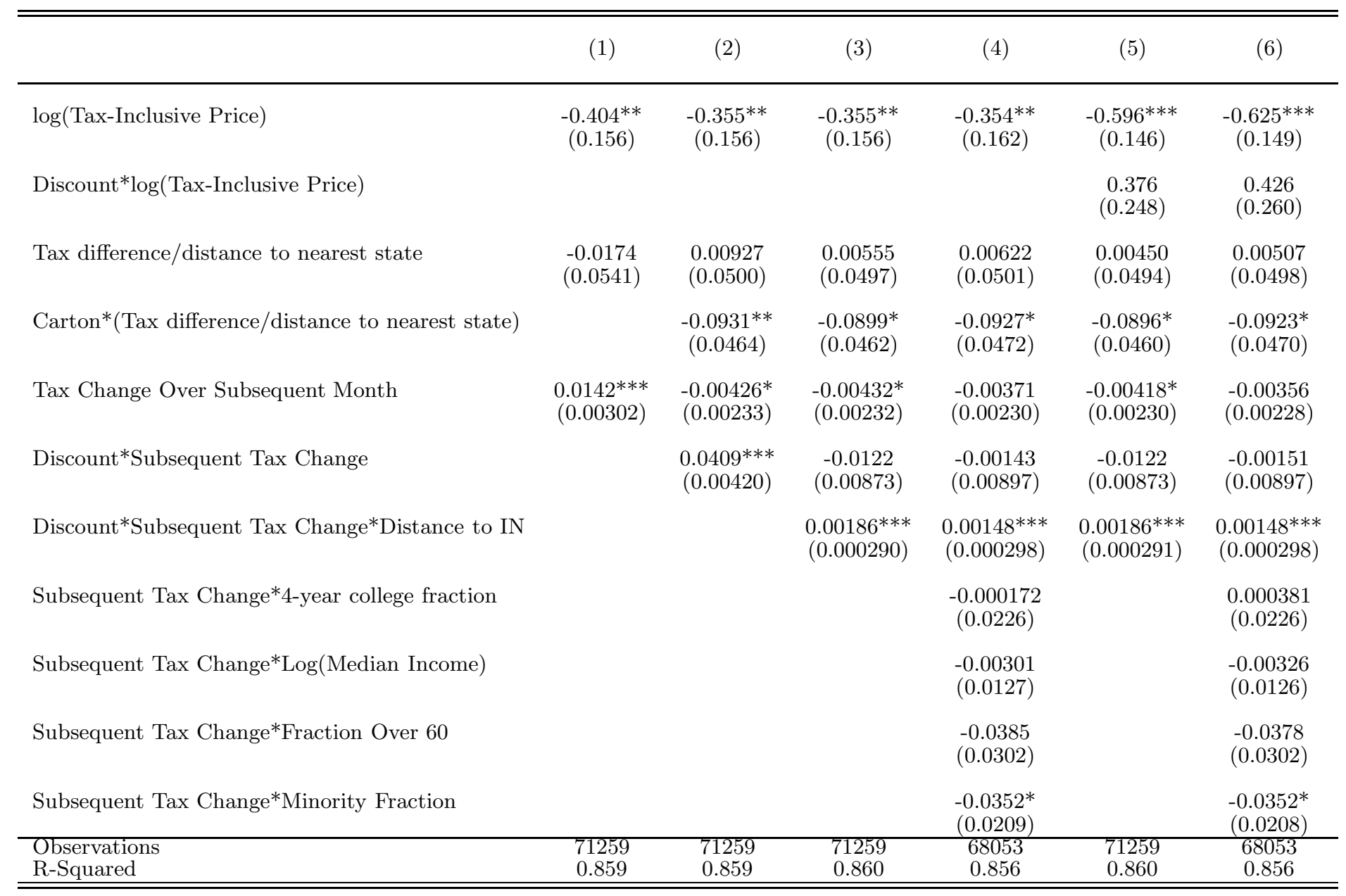

The dependent variable is the log of sales. All specifications include a quartic time trend, store fixed effects and carton*discount fixed effects. Taxes and average prices at other stores are used as instruments for price in the IV specifications. For specifications (5) and (6), we further interact excise tax and average prices with the discount indicator as instruments for the discount ${ }^{*} \log$ (Price) interaction term. Robust Standard Errors clustered at the store level. *, **, and *** denote significance at the $10 \%, 5 \%$ and $1 \%$ levels. 
Table 5: Discount Cigarette Market Share

\begin{tabular}{|c|c|c|c|c|c|}
\hline & (1) & $(2)$ & (3) & (4) & (5) \\
\hline Tax Per Pack & $\begin{array}{c}-0.000757^{* * *} \\
(0.000210)\end{array}$ & $\begin{array}{c}-0.000480^{* *} \\
(0.000220)\end{array}$ & $\begin{array}{c}-0.000956^{* * *} \\
(0.000215)\end{array}$ & $\begin{array}{c}-0.000851^{* * *} \\
(0.000211)\end{array}$ & $\begin{array}{c}-0.000694^{* * *} \\
(0.000216)\end{array}$ \\
\hline Tax Change Over Subsequent Month & & $\begin{array}{c}0.00456^{* * *} \\
(0.000383)\end{array}$ & & & $\begin{array}{c}0.00448^{* * *} \\
(0.000392)\end{array}$ \\
\hline Tax Change Over Preceding Month & & $\begin{array}{c}0.00241^{* * *} \\
(0.000288)\end{array}$ & & & $\begin{array}{c}0.00248^{* * *} \\
(0.000297)\end{array}$ \\
\hline Tax difference/Distance to nearest state & & & $\begin{array}{c}0.00312^{* * *} \\
(0.00110)\end{array}$ & & $\begin{array}{c}0.00186^{*} \\
(0.00105)\end{array}$ \\
\hline Tax Per Pack * $\log ($ Median Income $)$ & & & & $\begin{array}{c}0.000593 \\
(0.000717)\end{array}$ & $\begin{array}{c}0.000511 \\
(0.000702)\end{array}$ \\
\hline Tax Per Pack * Perc. of Customers with BA & & & & $\begin{array}{c}0.00150 \\
(0.00127)\end{array}$ & $\begin{array}{c}0.00177 \\
(0.00133)\end{array}$ \\
\hline Tax Per Pack * Perc. Minority Customers & & & & $\begin{array}{c}0.00310^{* *} \\
(0.00137)\end{array}$ & $\begin{array}{c}0.00278^{* *} \\
(0.00135)\end{array}$ \\
\hline Tax Per Pack * Perc. of Customers Over 60 & & & & $\begin{array}{c}0.00635^{* *} \\
(0.00254) \\
\end{array}$ & $\begin{array}{c}0.00562^{* *} \\
(0.00254) \\
\end{array}$ \\
\hline $\begin{array}{l}\text { Observations } \\
\text { R-Squared }\end{array}$ & $\begin{array}{l}24221 \\
0.356\end{array}$ & $\begin{array}{l}23538 \\
0.404\end{array}$ & $\begin{array}{l}24221 \\
0.358\end{array}$ & $\begin{array}{l}23414 \\
0.366\end{array}$ & $\begin{array}{l}22755 \\
0412\end{array}$ \\
\hline
\end{tabular}

Robust Standard Errors clustered at the store level. The dependent variable is the sales of discount cigarettes divided by total sales of all cigarettes. All specifications include store fixed effects and a quartic time trend. *, **, and ${ }^{* * *}$ denote significance at the $10 \%, 5 \%$ and $1 \%$ levels. 
Table 6: Cigarette Excise Tax Incidence

\begin{tabular}{|c|c|c|c|c|}
\hline & (1) & $(2)$ & (3) & $(4)$ \\
\hline$\Delta$ Cigarette Excise Tax (cpp) & $\begin{array}{c}0.525^{* * *} \\
(0.0149)\end{array}$ & $\begin{array}{l}0.605^{* * *} \\
(0.0179)\end{array}$ & & \\
\hline$\Delta$ Tax $*$ Carton & & $\begin{array}{c}-0.212^{* * *} \\
(0.0251)\end{array}$ & & \\
\hline$\Delta \operatorname{Tax} *$ Discount & & $\begin{array}{l}0.0606^{*} \\
(0.0363)\end{array}$ & & \\
\hline Premium Packs $* \Delta$ Tax & & & $\begin{array}{r}0.610^{* * *} \\
(0.0182)\end{array}$ & $\begin{array}{c}0.653^{* * *} \\
(0.0193)\end{array}$ \\
\hline Premium Cartons $* \Delta$ Tax & & & $\begin{array}{r}0.387^{* * *} \\
(0.0195)\end{array}$ & $\begin{array}{c}0.478^{* * *} \\
(0.0218)\end{array}$ \\
\hline Discount Packs $* \Delta$ Tax & & & $\begin{array}{c}0.640^{* * *} \\
(0.0383)\end{array}$ & $\begin{array}{c}0.676^{* * *} \\
(0.0392)\end{array}$ \\
\hline Discount Cartons $* \Delta \operatorname{Tax}$ & & & $\begin{array}{c}0.504^{* * *} \\
(0.0636)\end{array}$ & $\begin{array}{c}0.573^{* * *} \\
(0.0618)\end{array}$ \\
\hline$\Delta \operatorname{Tax} *($ Tax Diff / Dist to Border) & & & & $\begin{array}{c}-0.00828^{* * *} \\
(0.00128)\end{array}$ \\
\hline $\begin{array}{l}\text { Carton * } \\
\Delta \operatorname{Tax} *(\text { Tax Diff / Dist to Border })\end{array}$ & & & & $\begin{array}{c}-0.0129 * * * \\
(0.00317) \\
\end{array}$ \\
\hline $\begin{array}{l}\text { Observations } \\
\text { R-Squared }\end{array}$ & $\begin{array}{c}1119216 \\
0.0357\end{array}$ & $\begin{array}{c}1119216 \\
0.0371\end{array}$ & $\begin{array}{c}1119216 \\
0.0372\end{array}$ & $\begin{array}{c}1119216 \\
0.0379\end{array}$ \\
\hline
\end{tabular}

The dependent variable is the first-difference of the tax-inclusive price. All independent variables are first-differenced. All specifications include class-specific fixed effects. Robust Standard Errors clustered at the UPC level. *, **, and *** denote significance Rat the $10 \%, 5 \%$ and $1 \%$ levels. 